\title{
The contemporary importance and future of Sulawesi's ancient rock art
}

\author{
Paul S.C. Taçon, Muhammad Ramli, Budianto Hakim, \\ Adam Brumm and Maxime Aubert
}

\begin{abstract}
In October 2014, the world learned that the oldest surviving hand stencils and rock paintings of animals were located in southern Sulawesi rather than in Europe. These results, produced using uranium-series dating methods, were the first reported Pleistocene ages for figurative rock art imagery in Island Southeast Asia. We summarise this discovery and its significance in relation to associated research on the oldest rock art of Europe before discussing future research priorities including contemporary concerns about the rock art's conservation that resulted from discussions between the authors and others in 2015. This review is relevant for rock art research not only for the greater Sulawesi region but also many other parts of the world.
\end{abstract}

Keywords: rock art, dating, conservation, Toalean, Austronesian Painting Tradition

\section{Introduction}

Sulawesi has produced exciting archaeological discoveries of global significance for over 60 years, as this volume attests. From van Heekeren's $(1952,1957)$ early reports on intriguing stone tools and rock art to the recent publication of what may well be the world's oldest rock art, at least 40,000 years old (Aubert et al. 2014), to the more recent publications about stone tools dated to between 118,000 and 194,000 years BP (van den Bergh et al. 2016) and unique Pleistocene portable symbolic material culture (Brumm et al. 2017), Sulawesi has been at the forefront of our understanding of the long-term human history of Island Southeast Asia (ISEA), Sunda and even Sahul. In this paper, we focus on the rock art of Southwest Sulawesi, particularly paintings (Figure 4.1), stencils and drawings, and outline seven future research priorities in order to better understand the rock art imagery as well as the relationship between the artists and other peoples of nearby Borneo and even northern Australia. Furthermore, we argue that Sulawesi's significant rock art heritage is threatened by a range of natural and human threats necessitating conservation and management plans to be revisited (Taçon et al. 2014). 


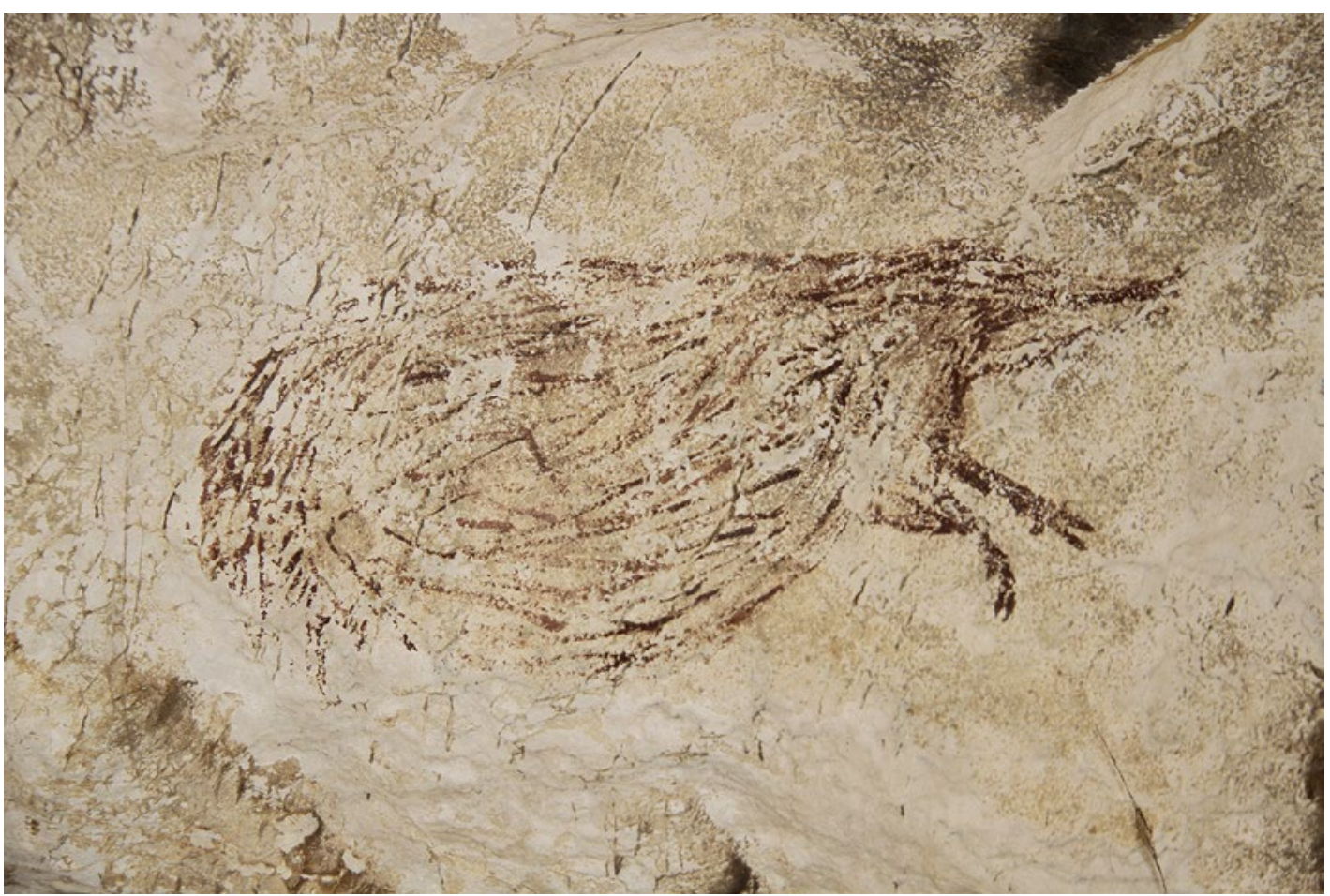

Figure 4.1: Early painting of a possible babirusa similar to one dated to over 35,000 years ago. Source: Photograph by Paul S.C. Taçon.

\section{Early rock art}

Research in Sulawesi is changing the traditional view that sophisticated 'cave art'-long seen as one of the paragons of early human creativity and innovation-originated in Europe. For instance, uranium-series dating has provided minimum and maximum ages for 12 hand stencils and two naturalistic animal paintings from seven sites in the limestone karsts of Maros, on the southern peninsula of Sulawesi. The earliest minimum age for a hand stencil is 39,900 years BP at Leang Timpuseng. The oldest animal painting, apparently depicting a female babirusa 'pig-deer' (see Hayes and van den Burgh, this volume), also at Leang Timpuseng, was made at least 35,400 years BP. A second animal painting (probably a pig) at another site has a minimum age of 35,700 years BP (Aubert et al. 2014). Other minimum and maximum ages of Maros District hand stencils indicate they were made over at least a 12,000-year period.

This challenges the view that figurative rock paintings and stencils first emerged in Europe as a red disc design from El Castillo, Spain (the oldest directly dated European rock art image; see Pike et al. 2012), and the Leang Timpuseng hand stencil are both at least 40,000 years of age. Furthermore, even if depictions of two 'fighting' rhinoceroses in France's Chauvet Cave are 32,410 \pm 720 radiocarbon years BP (about 35,000 calendar years BP) based on ${ }^{14} \mathrm{C}$ dating of charcoal pigment (see e.g. Quiles et al. 2016; Valladas et al. 2001, 2004), some Sulawesi paintings of animals are the same age or older. However, the animal paintings of Chauvet may be no more than 26,000 years BP according to Pettitt and Bahn (2015) (see also Combier and Jouve 2012, 2014). Carved ivory figurines from the Swabian Alps of Germany may actually be the oldest surviving animal depictions in Europe, some estimated to be 35,000 years old based on dated excavated material nearby (Conard 2003, 2007, 2009), but they are also younger than the Sulawesi paintings. 
Importantly, the hand stencils and animal paintings of Sulawesi closely resemble those of nearby eastern Kalimantan (Indonesian Borneo; e.g. Fage and Chazine 2009; Plagnes et al. 2003) and the two areas may well be part of a very early regional tradition, despite the large expanse of water separating them. Indeed, early rock art consisting of naturalistic animals and sometimes hand stencils can be found in many parts of Southeast Asia (Taçon, Tan et al. 2014) and northern Australia (Chaloupka 1993), and some examples may be equally old. However, we caution against arguing that they represent the work of closely related peoples, emphasising instead that 'humans have a shared rock-making legacy that includes the production of naturalistic depictions of animals and that motifs of these kinds should not be viewed as evidence of particular ethnicities' (Taçon, Tan et al. 2014:1062).

This recent dating of cave paintings in Maros has altered our understanding of the origins and spread of the first painting traditions, suggesting that rock art developed independently in Europe and Southeast Asia at about the same time, or that our species invented this trait prior to its initial expansion from Africa. Gibbons (2014:1447) reports for Science that 'The finding could rewrite the history of a key stage in the development of the human mind'. In this regard, she is referring to the fact that the Sulawesi rock art dates strongly indicate that a 'symbolic explosion' in Europe did not bring about the modern human mind but rather it has its origins much earlier in Africa (Aubert et al. 2014; Taçon, Tan et al. 2014).

\section{Future research priorities}

Given this significance and the resulting international attention Sulawesi rock art is receiving, we suggest seven future research priorities. In various ways, some of these priorities apply for parietal art in other regions of Southeast Asia, as well as other parts of the world.

\section{Survey and recording}

Until recently, there were 127 known sites in the Maros-Pangkep karst region (Said et al. 2007; Tim Penelitian 2011) but each year new discoveries are made. For instance, with Indonesian colleague Adhi Agus Oktaviana, dozens more sites were found in mid-2017. However, most sites have not been recorded in great detail due to time and budget constraints and other logistical issues. Detailed recording and survey across southern Sulawesi will give us a comprehensive database of information for conservation, interpretation and comparison to other regions. Some important sites should be recorded in high-resolution 3D for public replications in museums and interpretation centres, and for rock art conservation (see below). Of course, more survey and recording are important in any region, but there are significant portions of the Maros-Pangkep landscape that have not been assessed archaeologically that have huge potential. Furthermore, because of the age of paintings and stencils that have been scientifically dated, there is likely much more very early rock art that, when described and dated, will flesh out our understanding of this aspect of Pleistocene symbolic behaviour. Unfortunately, due to industrial development across southern Sulawesi that needs limestone for cement and other products, there is an urgency to locate and document rock art throughout the karst region before sites are lost forever. 


\section{Scientific rock art dating}

As noted above, ancient hand stencils and some paintings of animals are also common at what are argued to be the oldest Kalimantan rock art sites (Plagnes et al. 2003; Fage and Chazine 2009). New dates from both types of Kalimantan rock art as part of a project led by Maxime Aubert and Pindi Sttiawan (ARCHE 2016) will be published soon. More dating of these forms of Sulawesi and Kalimantan rock art needs to be undertaken. Various forms of Holocene rock art also need to be directly dated (Figure 4.2, and see below).

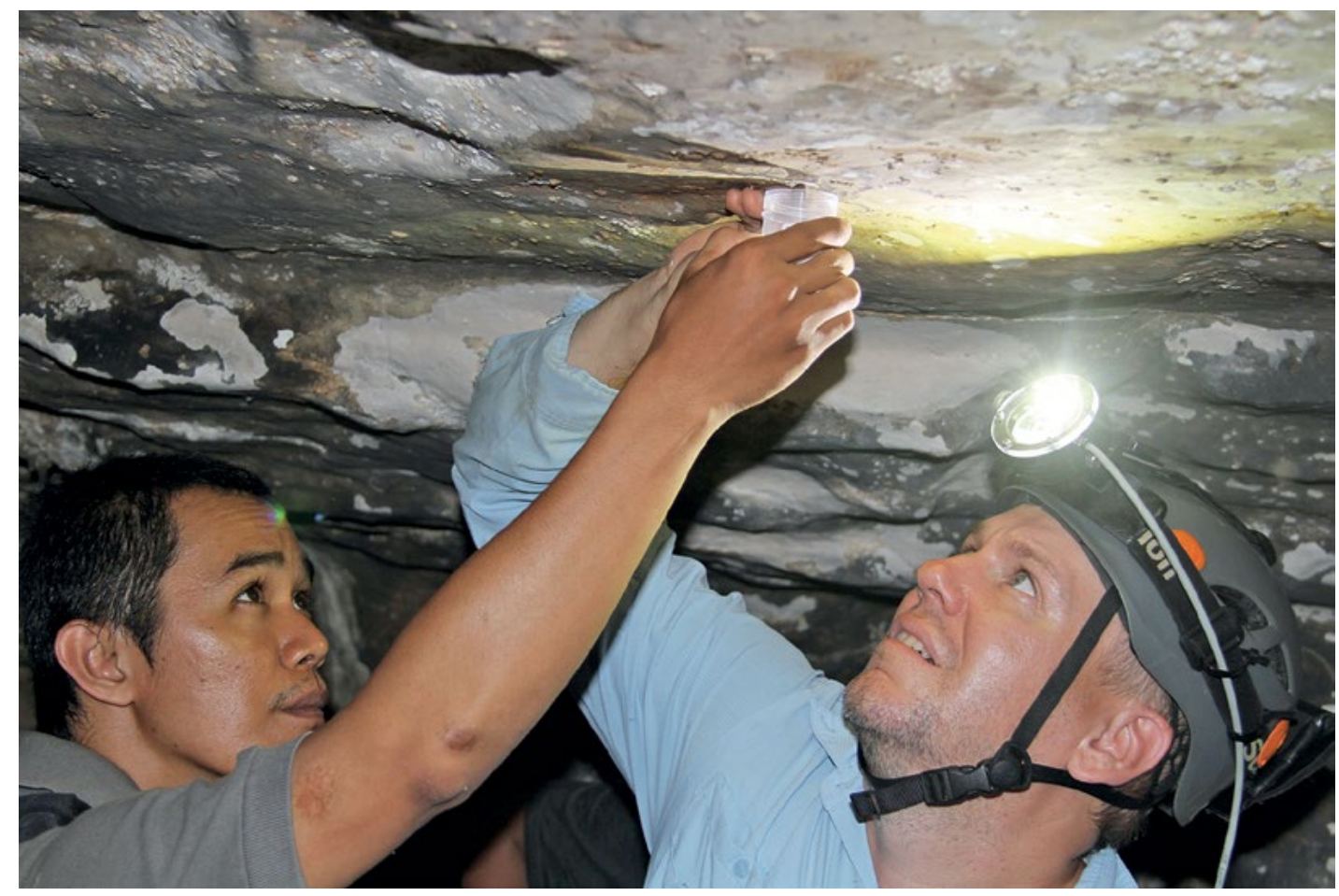

Figure 4.2: Mubarak Andi Pampang and Maxime Aubert sampling for rock art dating.

Source: Photograph by Paul S.C. Taçon.

\section{Pleistocene connections}

Importantly, Sulawesi rock art is about the same age as the Deep Skull found in the Great Cave of Niah in Sarawak, Malaysian Borneo. The Deep Skull was recently redated to about 39,000 45,000 years BP, although it is more likely around 37,000 years old (Barker et al. 2013; Hunt and Barker 2014). The relationship between people who inhabited Niah Cave 37,000 years ago and the artists who made animal paintings and hand stencils in the Maros region of Sulawesi and eastern Kalimantan at this time would be important to explore but would depend on the recovery of fossil human material of this age in southern Sulawesi or eastern Kalimantan, DNA extraction, further rock art dating and further Pleistocene rock art discoveries between Niah and the eastern Kalimantan rock art sites.

In northern Australia, there are archaeological sites as old or older (e.g. see Clarkson et al. 2017), and the earliest art also consists of stencils and large naturalistic animals, including extinct species, based on the superimposition of different styles (Chaloupka 1993; Taçon, Langley et al. 2010; Taçon, Tan et al. 2014), as in ISEA and Western Europe. Some Australian rock art may be just as old but not yet dated. And some Kalimantan human-like figures (Fage and Chazine 2009) resemble Australian Dynamic Figures of Arnhem Land, Australia (Chaloupka 1993) and 
Elegant Action Figures of the Kimberley (Walsh 2000). Perhaps there were ancient Pleistocene connections across the region or shared cultural practices that first peoples brought with themthis needs further scientific investigation.

The relationship between Pleistocene parietal art and portable symbolic material culture also needs better exploration as a recent publication by Brumm et al. (2017) highlights. They found 'an unusually rich and unique symbolic complex' in archaeological deposits dated to between 30,000 to 22,000 years ago (Brumm et al. 2017:4105) consisting of disc-shaped beads from a Babyrousa sp. lower incisor, a perforated Ailurops ursinus phalanx 'pendant', five stone artefacts with incised lines, as well as pigmented artefacts. This suggests that there was a rich array of symbolic behaviour practised in Pleistocene Sulawesi manifest in many ways, including rock art and portable material culture, just as in Pleistocene Europe.

\section{Toalean rock art?}

But what of more recent rock art in Sulawesi? Was there a Holocene Toalean rock art tradition? Bulbeck et al. (2000) have described a prehistoric hunter-gatherer culture traditionally glossed as 'Mesolithic' in nature, which occupied South Sulawesi; this so-named Toalean culture is specifically 'applied to microlithic assemblages in South Sulawesi with an age range between c. 8000 and 1500 B.P.' (Bulbeck et al. 2000:71). These hunter-gatherers were able to travel distances of up to $30 \mathrm{~km}$ to offshore islands (Bulbeck et al. 2000:94). Could they have also made rock art?

For instance, at some Maros sites there are rare small paintings of humans and animals in red outline that are very different to the earliest red rock art referred to above and late Holocene charcoal designs. A number of these can be found at the Maros area site Leang Jing (see Figure 4.3). Our initial impression, based on superimpositions and other field observations, is that they appear to be more recent than the old, large animal paintings and stencils. Were these 'intermediate' images made by the Toaleans? We do not have direct dates, so this art needs to be dated and further investigated.

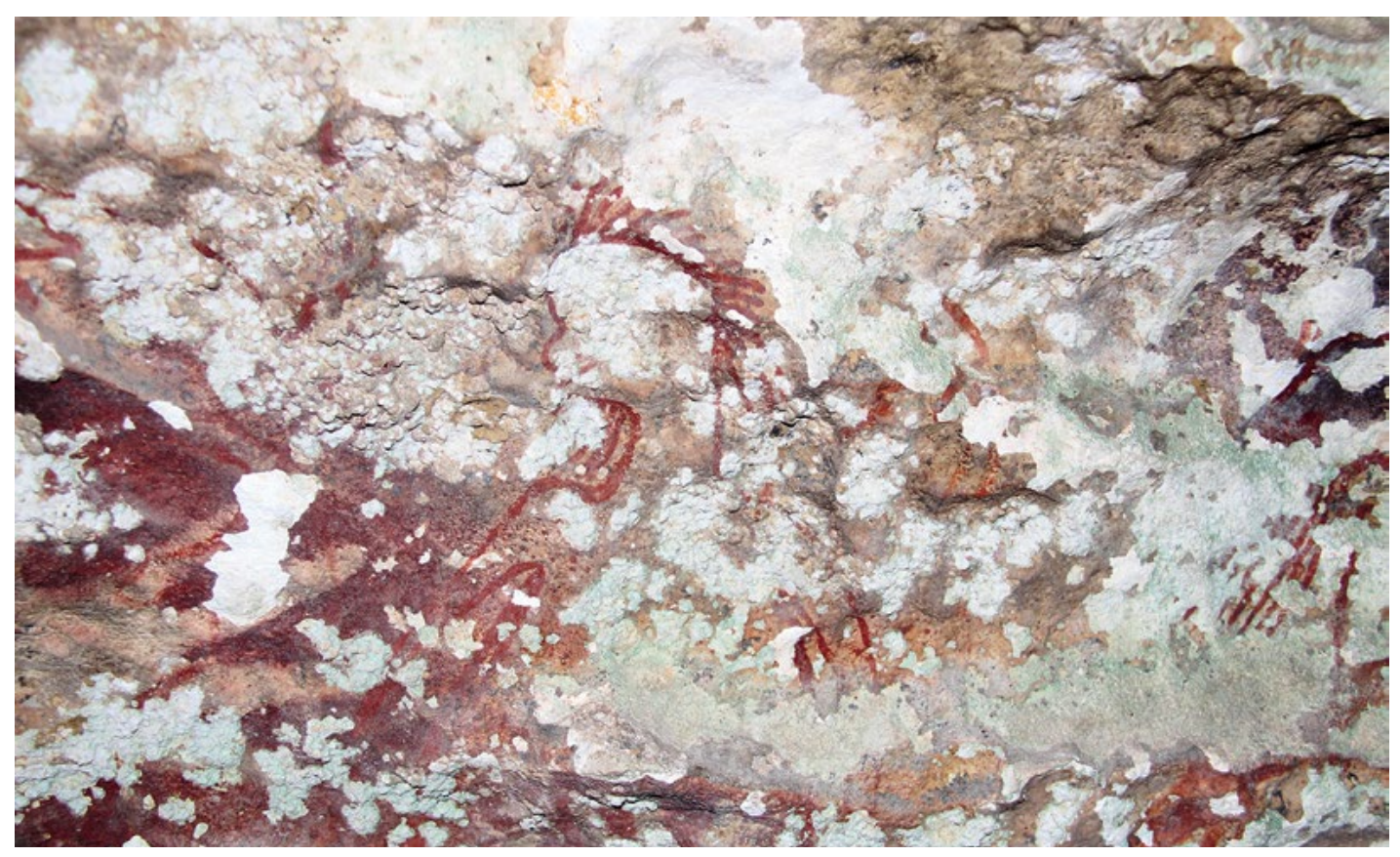

Figure 4.3: Intermediate red painting of a human figure from Leang Jing.

Source: Photograph by Paul S. C. Taçon. 


\section{Charcoal rock art}

As noted above, there may be connections between the old red Pleistocene rock art of Sulawesi and Borneo in terms of hand stencils and naturalistic animal depictions. Is there a relationship for the recent Holocene charcoal-based rock art as well? For instance, many charcoal drawings and recent engravings of human figures, animals and abstract designs in Borneo, Sulawesi and other parts of ISEA are stylistically similar, including rare Sabah engravings and charcoal rock art, found by the Malaysian archaeologist Mokhtar Saidin in a remote part of Sabah in 2007 (Mokhtar 2008; Mokhtar et al. 2008).

Did Austronesian farming culture and rock art-the so-named 'Austronesian Painting Tradition'-emerge in Sulawesi and nearby parts of Indonesia rather than come from Taiwan? The situation is likely complex and not quite an either/or scenario, as Bulbeck (2008), Taçon, Aubert and Brumm (2014), O'Connor (2015), Hoerman (2016) and others point out. Thus we need to better describe and compare Sulawesi charcoal drawings to similar designs across the region (e.g. compare Figures 4.4 and 4.5). These designs also need to be directly dated. An initial result from samples obtained from a site in Maros as part of an ongoing rock art dating research program will be available soon.

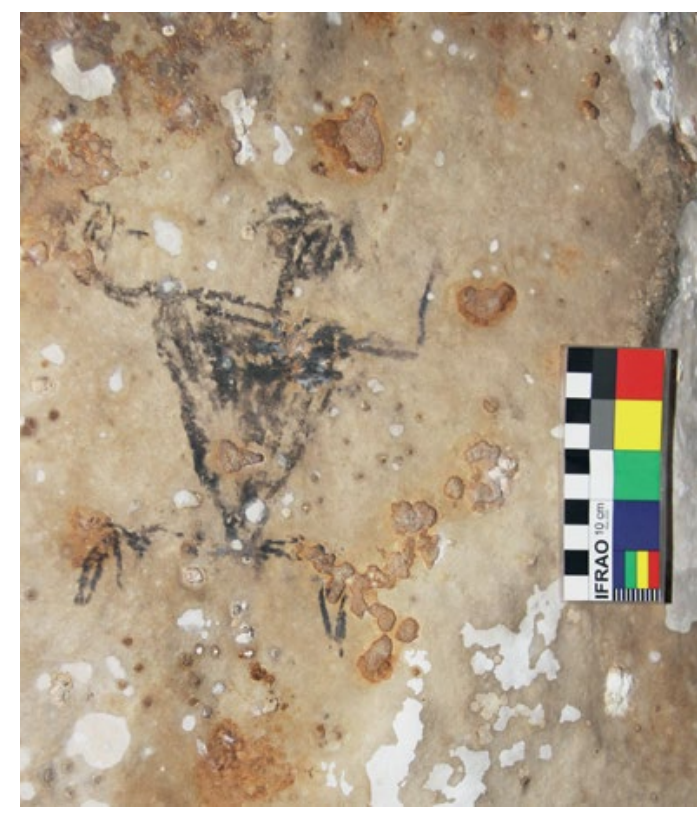

Figure 4.4: Charcoal human figure from Sampeang 1, Maros region, Sulawesi.

Source: Photograph by Paul S.C. Taçon.

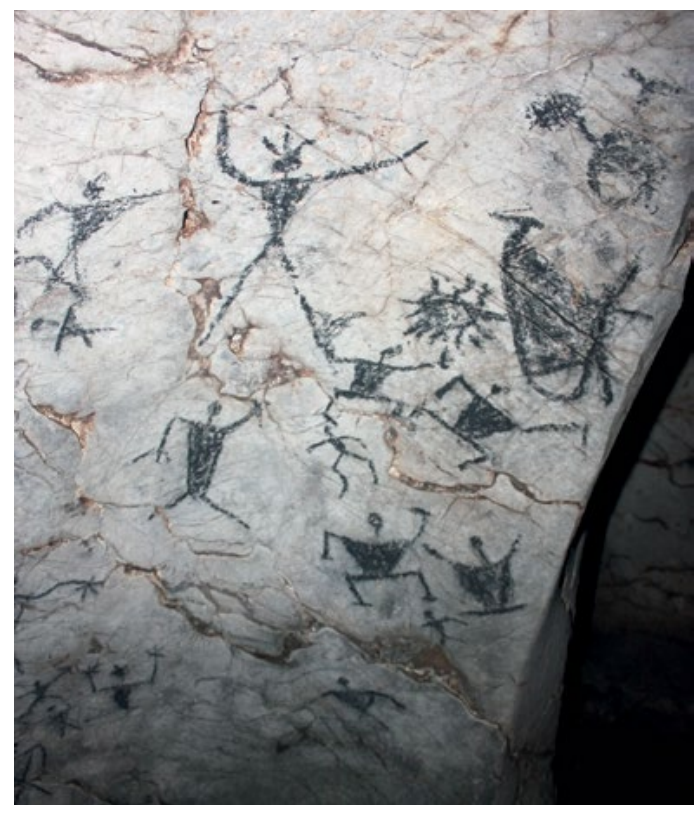

Figure 4.5: Charcoal human figure from Gua Sireh, Sarawak, Malaysia.

Source: Photograph by Paul S.C. Taçon.

\section{Holocene Sulawesi: Northern Australia connections}

Traditional Owners of northern Australia, such as Ronald Lamilami and his son Patrick, Mawng men of the Namunidjbuk clan, refer to their Wellington Range rock art sites in northwest Arnhem Land as their history books, their libraries (Agnew et al. 2015:15). Sulawesi rock art sites can be viewed similarly in that they provide a rich visual record of some periods of the past. The Namunindjbuk Estate was visited by people from Macassar ${ }^{1}$ for hundreds of years (Macknight 1976; Taçon, May et al. 2010; Wesley et al. 2016) and records of this can be found at rock art sites.

1 The Dutch colonial spelling for the city prior to Indonesia’s independence when the Indonesian spelling of Makassar came into use. 
For instance, the Malarrak rock art site has paintings of a perahu sailing boat, a badi' (a type of iron dagger from Southwest Sulawesi; Figure 4.6) and possibly a monkey in a tree (Taçon and May 2013; but also see May et al. 2013 for interpretation that a quoll might have been depicted). A second site, Djulirri, has a white perahu with a minimum age between AD 1644 and 1802 (median age of 1777$)^{2}$ as well as a large yellow painting of a perahu that is older. The perahu painting is under a beeswax snake that was radiocarbon dated. The beeswax snake has been Carbon-14 dated to $\mathrm{AD} 1624-1674$ (94\% accuracy; using OxCal4.1) or 1517-1664 with a median age of 1577 (99\% accuracy using IntCal09) (Taçon, May et al. 2010). ${ }^{3}$ This sits comfortably with results from recent excavations at a Macassan trepang processing site on the nearby coast that indicates people from Macassar were visiting as early as AD 1637 (Wesley et al. 2016).

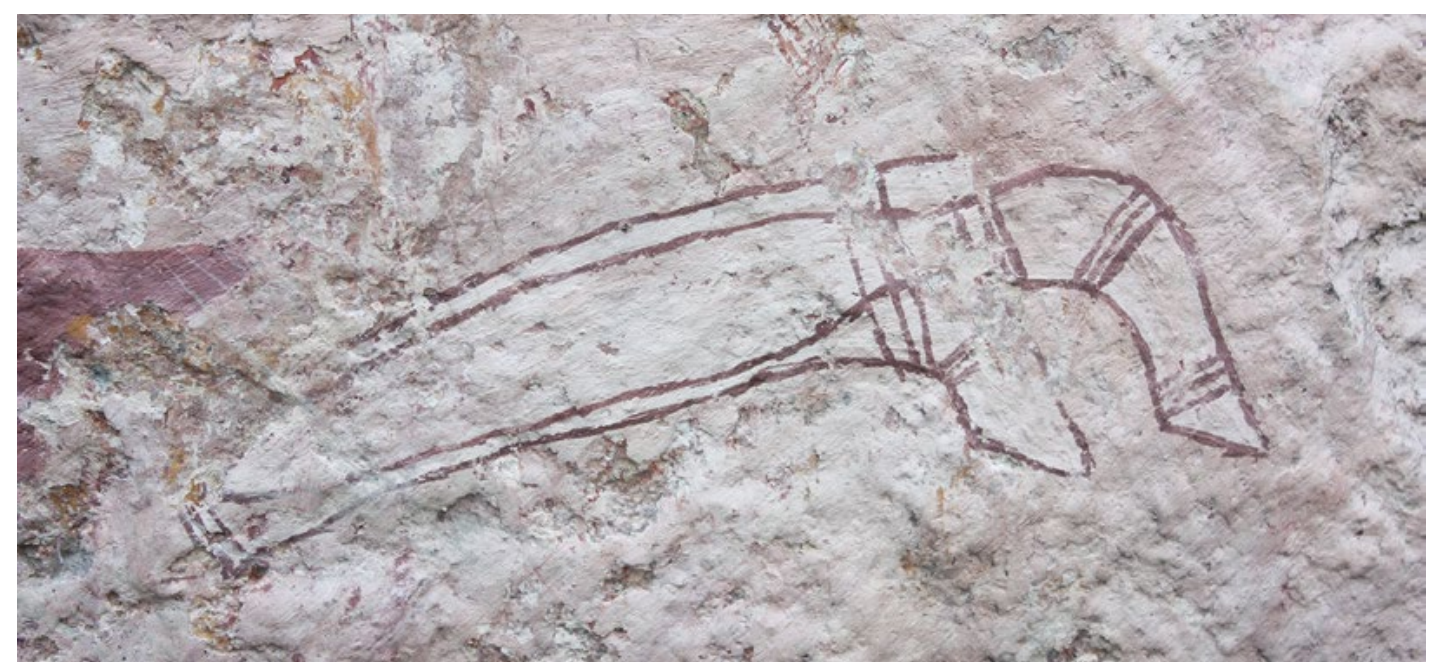

Figure 4.6: Rock painting of a badi' (a type of iron dagger from Southwest Sulawesi) at the Malarrak site, Wellington Range, northwest Arnhem Land.

Source: Photograph by Paul S.C. Taçon.

Future research could look for earlier rock art and other connections between Sulawesi, Borneo and northern Australia as canine DNA and other evidence suggests some group of people from the Borneo-Sulawesi region probably brought the dog (dingo) to Australia about 4000 years ago (see review in Fillios and Taçon 2016).

\section{Rock art conservation}

World rock art is disappearing at an increasing rate and Southeast Asia is particularly vulnerable. Sulawesi's rock art, like that of most countries, faces a wide range of natural and human threats (Agnew et al. 2015; Lambert 2007; Taçon 2013; Taçon and Marshall 2014). Natural threats, such as general weathering, water washing over surfaces, changes in exposure to sunlight, vegetation, deterioration of rock surfaces, damage by animals such as termites and mud wasps that build nests over rock art panels and other environmental forces are difficult, if not impossible, to fully protect against. However, human impacts, such as development, feral animals, road dust, unauthorised visitation, graffiti, theft, vandalism and so forth can be better controlled against. Although various forms of legislation in many countries make it an offence to disturb a rock art site, this has not stopped a rise in graffiti, vandalism and damage from development. Furthermore, sites open to the public often do not have appropriate infrastructure and are not monitored effectively. Graffiti, vandalism, development and even tourism threaten sites across the world.

2 Between 306 and 148 years BP, with a median age of 173 years BP.

3 Respectively, 326-276 years BP, and 433-286 with a median age of 373 years BP. 
In Australia and Indonesia, we need to find new ways to look after our rock art before it is gone forever and to continue to pass on our knowledge to younger generations and each other. Key issues for Sulawesi include:

(a) Graffiti (Figure 4.7) is an increasing problem in parts of Sulawesi that could be addressed through education, increased site monitoring and new forms of access restrictions.

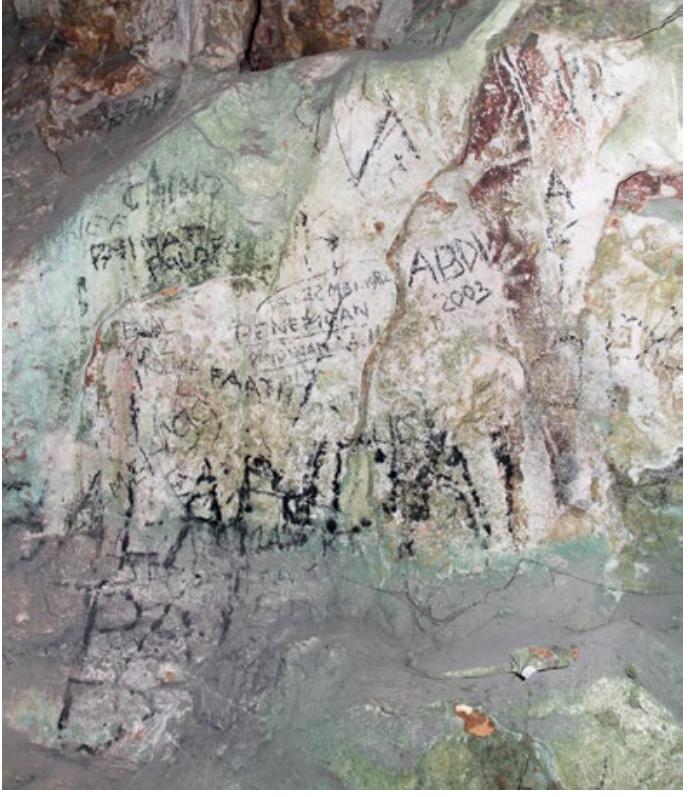

Figure 4.7: Graffiti is a growing threat to Maros rock art sites and to rock art globally. (b) Various forms of development, including cement processing, marble quarrying and resulting new dusty roads is another growing risk for rock art.

(c) One of us (Muhammad Ramli) and others have noticed that many stencils and old animal paintings have been lost or damaged since the early 1980s due to a rapid increase in flaking of limestone surfaces (Figure 4.8).

(d) There are local people who look after rock art sites and some sites have signs and locked gates but future tourist pressure will require revised management and conservation plans. This could include a 3D scanning program of the more important sites so that should something catastrophic happen to them a detailed permanent record would be available for replication.

Source: Photograph by Paul S.C. Taçon.

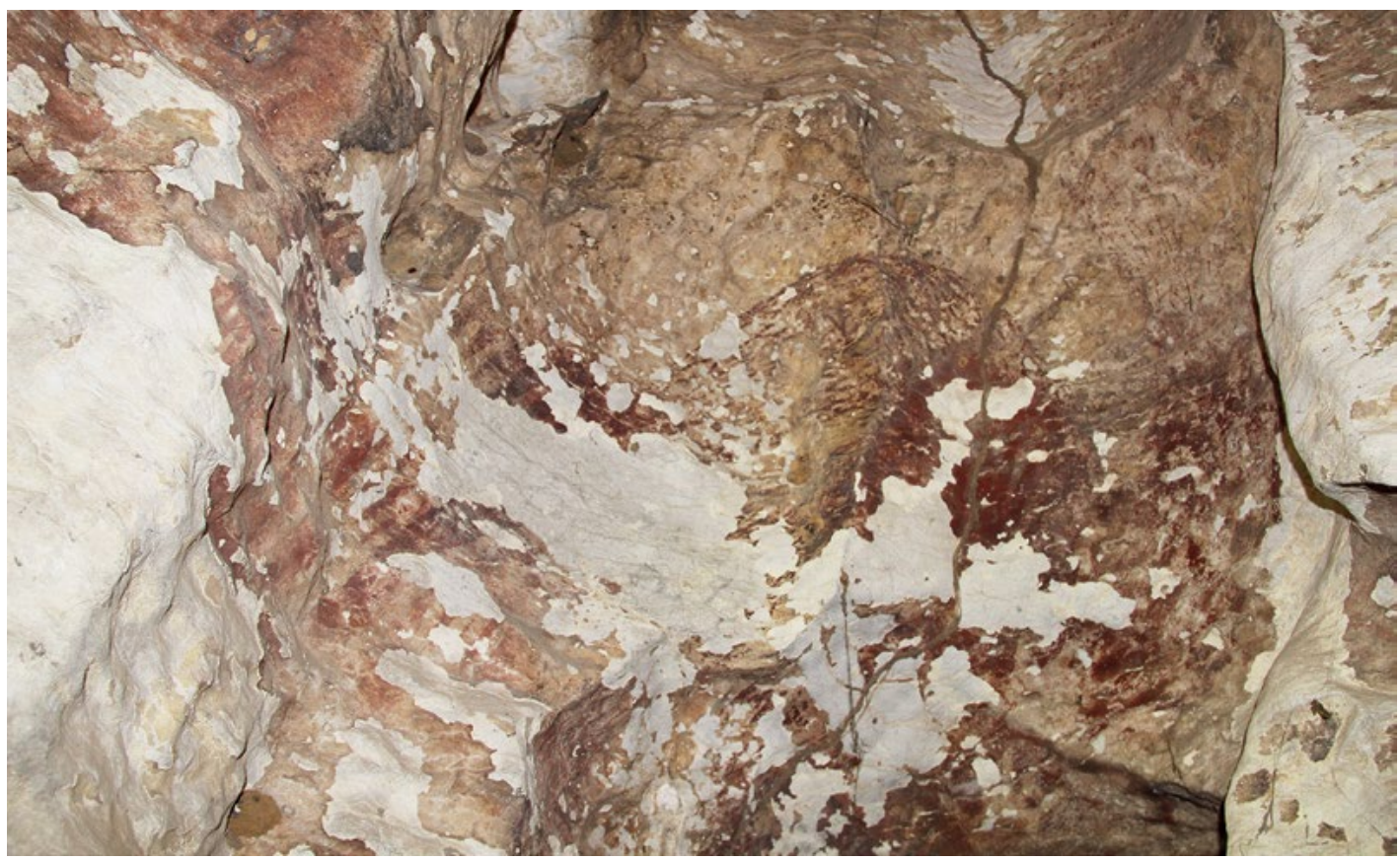

Figure 4.8: There appears to have been an increase in flaking of limestone surfaces since the 1980s, damaging paintings, stencils and drawings in the process.

Source: Photograph by Paul S.C. Taçon. 


\section{Summary and conclusion}

After ongoing discussions between the authors and many other people that began in June 2015, we conclude that new research on Sulawesi rock art should focus on six priorities. The first consists of survey in areas not yet considered and detailed recording at sites deemed significant and/or under threat. The second priority is more rock art dating, which will assist with the third of exploring the nature of Pleistocene connections between Sulawesi, Borneo and possibly northern Australia. We also need to better understand the Holocene rock art with a study of red outline paintings such as at Leang Jing and by describing and comparing Sulawesi charcoal rock art to that of Borneo and other parts of ISEA. This will then allow us to better explore the nature of mid to late Holocene connections between Sulawesi and Borneo, and very recent connections with northern Australia. The sixth priority would involve research on new ways to conserve Sulawesi rock art for future generations, focusing especially on (a) graffiti, (b) development pressures, (c) changes to cave environments and (d) tourism. Through future collaborations between us and other colleagues in both Indonesia and Australia, we hope to address these priorities and, indeed, two new projects commenced in 2017.

By studying rock art, we can learn about ancient cultures, their spirituality, history and relationships to land. The art also informs us about past periods of environmental change, what long-extinct animals looked like, reactions to the arrival of outsiders from various places and many other things. Rock art sites are museums and art galleries embedded in natural landscapes with ongoing cultural connection for contemporary peoples. Unlike built museums/galleries rock art sites do not have high security, protection from the elements or the financial support required to conserve them into the future. This is why it is important to develop a comprehensive and fully funded conservation and management program for Sulawesi's rock art—so that the world's oldest surviving rock art continues to be available to future generations.

\section{Acknowledgements}

We thank Griffith University, Balai Pelestarian Cagar Budaya Makassar and Balai Arkeologi Makassar for supporting this research and allowing us to participate in 'The Archaeology of Sulawesi' symposium. The symposium organisers are thanked for inviting us to contribute to this volume. Two anonymous referees provided comments on an earlier version of this paper.

\section{Author biographies}

Paul S.C. Taçon Evolution and Rock Art Heritage Unit, Griffith Centre for Social and Cultural Research, Australian Research Centre of Human Evolution and School of Humanities, Languages and Social Science, Gold Coast campus, Griffith University, Queensland, Australia

Muhammad Ramli Balai Pelestarian Cagar Budaya Makassar, South Sulawesi, Indonesia

Budianto Hakim Makassar Archaeology Office, Makassar, South Sulawesi, Indonesia

Adam Brumm Australian Research Centre of Human Evolution, Environmental Futures Research Institute, Nathan campus, Griffith University, Queensland, Australia

Maxime Aubert Evolution and Rock Art Heritage Unit, Griffith Centre for Social and Cultural Research, Australian Research Centre of Human Evolution and School of Humanities, Languages and Social Science, Gold Coast campus, Griffith University, Queensland, Australia 


\section{References}

Agnew, N., J. Deacon, N. Hall, T. Little, S. Sullivan and P.S.C. Taçon. 2015. Rock Art: A Cultural Treasure at Risk. Los Angeles: Getty Conservation Institute.

ARCHE (Australian Research Centre of Human Evolution). 2016. Rock art research. www.griffith.edu.au/ environmental-futures-research-institute/research-centre-human-evolution (accessed 27 October 2018).

Aubert, M., A. Brumm, M. Ramli, T. Sutikna, E.W. Saptomo, B. Hakim, M.J. Morwood, G.D. van den Bergh, L. Kinsley and A. Dosseto. 2014. Pleistocene cave art from Sulawesi, Indonesia. Nature 514(7521):223-227, doi.org/10.1038/nature13422 (accessed 5 June 2018).

Barker, G., H. Barton, F. Cole, C. Doherty, D. Gilbertson, C. Hunt, L. Lloyd-Smith, P. Piper, R. Rabett, T. Reynolds and K. Szabó. 2013. The Niah Caves, the 'human revolution', and foraging/farming transitions in island Southeast Asia. In G. Barker (ed.), Rainforest Foraging and Farming in Island Southeast Asia: The Archaeology of the Niah Caves, Sarawak, Vol. 1, pp. 341-366. Cambridge: McDonald Institute for Archaeological Research.

Brumm, A., M.C. Langley, M.W. Moore, B. Hakim, M. Ramli, I. Sumantri, B. Burhan, Andi M. Saiful, L. Siagian, Suryatmane, R. Sardi, A. Jusdi, Abdullahj, A. Pampan Mubarakj, Haslianae, Hasriantie, A. A. Oktaviana, S. Adhityatamak, G. D. van den Bergh, M. Aubert, J. Zhao, J. Huntley, B. Lil, R.G. Roberts, E. Wahyu Saptomok, Y. Perstond and R. Grün. 2017. Early human symbolic behavior in the Late Pleistocene of Wallacea. PNAS 114(16):4105-4110, available at www.pnas.org/ content/114/16/4105 (accessed 5 June 2018).

Bulbeck, D. 2008. An integrated perspective on the Austronesian diaspora: The switch from cereal agriculture to maritime foraging in the colonisation of Island Southeast Asia. Australian Archaeology 67(Dec. 2008):31-52. doi.org/10.1353/asi.2000.0004 (accessed 5 June 2018).

Bulbeck, D., M. Pasqua and A. Di Lello. 2000. Culture history of the Toalean of South Sulawesi, Indonesia. Asian Perspectives 39(1-2):71-108.

Chaloupka, G. 1993. Journey in Time. The World's Longest Continuing Art Tradition: The 50,000 Year Story of the Australian Aboriginal Rock Art of Arnhem Land. Chatswood: Reed Books.

Clarkson, C., Z. Jacobs, B. Marwick, R. Fullagar, L. Wallis, M. Smith, R.G. Roberts, E. Hayes, K. Lowe, X. Carah, S.A. Florin, J. McNeil, D. Cox, L.J. Arnold, Q. Hua, J. Huntley, H.E.A. Brand, T. Manne, A. Fairbairn, J. Shulmeister, L. Lyle, M. Salinas, M. Page, K. Connell, G. Park, K. Norman, T. Murphy and C. Pardoe. 2017. Human occupation of Australia by 65,000 years. Nature 547(7663):306-310. doi.org/10.1038/nature22968 (accessed 5 June 2018).

Combier, J. and G. Jouve. 2012. Chauvet cave's art is not Aurignacian: a new examination of the archaeological evidence and dating procedures. Quartär 59(1):131-152.

Combier, J. and G. Jouve. 2014. Nouvelles recherches sur l'identité culturelle et stylistique de la grotte Chauvet et sur sa datation par la méthode du 14C. L'Anthropologie 118(2):115-151. doi.org/10.1016/ j.anthro.2013.12.001 (accessed 5 June 2018).

Conard, N.J. 2003. Palaeolithic ivory sculptures from southwestern Germany and the origins of figurative art. Nature 426(6968):830-832. doi.org/10.1038/nature02186 (accessed 5 June 2018).

Conard, N.J. 2007. De nouvelles sculptures en ivoire aurignaciennes du Jura Souabe et la naissance de l'art figurative. In H. Floss and N. Rouquerol (eds), Les chemins de l'art Aurignacien en Europe. Das Aurignacien und die Anfänge der Kunst in Europa, pp. 317-330. Aurignac: Éditions Musée-forum Aurignac.

Conard, N.J. 2009. A female figurine from the basal Aurignacian of Hohle Fels Cave in southwestern Germany. Nature 459(7244):248-252. doi.org/10.1038/nature07995 (accessed 5 June 2018). 
Fage, L.-H. and J.-M. Chazine (eds). 2009. Bornéo: la mémoire des grottes. Lyon: Fage editions.

Fillios, M.A. and P.S.C. Taçon. 2016. Who let the dogs in? A review of the recent genetic evidence for the introduction of the dingo to Australia and implications for the movement of people. Journal of Archaeological Science: Reports 7:782-792. doi.org/10.1016/j.jasrep.2016.03.001 (accessed 5 June 2018).

Gibbons, A. 2014 (8 October). Indonesian cave art may be the world's oldest. Science Magazine 346:1447.

Hayes, S. and G. van den Bergh. 2018. Cave art, art and geometric morphometrics: Shape changes and the babirusa of Sulawesi. In S. O'Connor, D. Bulbeck and J. Meyer (eds), The Archaeology of Sulawesi: Current Research on the Pleistocene to the Historic Period, pp. 43-60. Canberra: ANU Press.

Hoerman, R. 2016. Utilizing Rock Art to Trace Human Migration: Case Studies from Sarawak, Malaysian Borneo. Unpublished PhD thesis. Honolulu: University of Hawai' $\mathrm{i}$.

Hunt, C. and G. Barker. 2014. Missing links, cultural modernity and the dead: Anatomically modern humans in the Great Cave of Niah (Sarawak, Borneo). In R. Dennell and M. Porr (eds), Southern Asia, Australia, and the Search for Human Origins, pp. 90-107. Cambridge: Cambridge University Press. doi.org/10.1017/CBO9781139084741.008 (accessed 5 June 2018).

Lambert, D. 2007. Rock Art Conservation Guidelines. Sydney: NSW Office of Environment \& Heritage.

Macknight, C.C. 1976. The Voyage to Marege': Macassan Trepangers in Northern Australia. Melbourne: Melbourne University Press.

May, S.K., P.S.C. Taçon, A. Paterson and M. Travers. 2013. The world from Malarrak: Depictions of South-East Asian and European subjects in rock art from the Wellington Range, Australia. Australian Aboriginal Studies 1(2013):45-56.

Mokhtar, S. 2008. Malaysian prehistoric works of art. In N.A.D. Mohamed (ed.), Susurmasa/Timelines. Seni Lukis Malaysia Bersama 50 Tahun Balai Seni Lukis Negara/Malaysian Art with 50 years National Art Gallery, pp. 32-39. Kuala Lumpur: National Art Gallery Malaysia.

Mokhtar, S., P.S.C. Taçon, D. Yang, G. Nash, S.K. May and B. Lewis. 2008. Illustrating the past: The rock art of Southeast Asia. Current World Archaeology 29:40-48.

O'Connor, S. 2015. Rethinking the Neolithic in Island Southeast Asia, with particular reference to the archaeology of Timor-Leste and Sulawesi. Archipel 90:15-48. doi.org/10.4000/archipel.362 (accessed 5 June 2018).

Pettitt, P. and P. Bahn. 2015. An alternative chronology for the art of Chauvet cave. Antiquity 89(345):542-553. doi.org/10.15184/aqy.2015.21 (accessed 5 June 2018).

Pike, A.W.G., D.L. Hoffmann, M. García-Diez, P.B. Pettitt, J. Alcolea, R. De Balbín, C. González-Sainz, C. de las Heras, J.A. Lasheras, R. Montes and J. Zilhão. 2012. U-Series Dating of Paleolithic Art in 11 Caves in Spain. Science 336(6087):1409-1413. doi.org/10.1126/science.1219957 (accessed 5 June 2018).

Plagnes, V., C. Causse, M. Fontugne, H. Valladas, J.-M. Chazine and L.-H. Fage. 2003. Cross dating (Th/U-14C) of calcite covering prehistoric paintings in Borneo. Quaternary Research 60(2):172-179.

Quiles, A., H. Valladas, H. Bocherens, E. Delqué-Količ, E. Kaltnecker, J. van der Plicht, J.-J. Delannoy, V. Feruglio, C. Fritz, J. Monney, M. Philippe, G. Tosello, J. Clottes and J.-M. Geneste. 2016. A highprecision chronological model for the decorated Upper Paleolithic cave of Chauvet-Pont d'Arc, Ardèche, France. Proceedings of the National Academy of Sciences 113(17):4670-4675. doi.org/10.1073/ pnas.1523158113 (accessed 5 June 2018).

Said, M.A., M. Hum, M. Ramli and I. Sumantri (eds). 2007. Directory ofCultural Potency at Maros-Pangkep Karst Area South Sulawesi Indonesia. Makassar: Balai Pelestarian Peninggalan Purbakala Makassar. 
Taçon, P.S.C. 2013. Australia’s rock art heritage: Past knowledge for a richer future. The Sarawak Museum Journal LXXI(92):49-79.

Taçon, P.S.C., M. Aubert and A. Brumm. 2014 (9 October). 40,000 year old rock art found in Indonesia. The Conversation. theconversation.com/40-000-year-old-rock-art-found-in-indonesia-32674 (accessed 5 June 2018).

Taçon, P.S.C. and M. Marshall. 2014. Conservation or crisis? The future of rock art management in Australia. In Y. Zhang (ed.), A Monograph of Rock Art Research and Protection, pp. 119-141. Beijing: Zhong Guo Zang Xue Chu Ban She/China Tibetology Publishing House.

Taçon, P.S.C., S.K. May, S.J. Fallon, M. Travers, D. Wesley and R. Lamilami. 2010. A minimum age for early depictions of Southeast Asian praus in the rock art of Arnhem Land, Northern Territory. Australian Archaeology 71:1-10. doi.org/10.1080/03122417.2010.11689379 (accessed 5 June 2018).

Taçon, P.S.C. and S.K. May. 2013. Rock art evidence for Macassan-Aboriginal contact in northwestern Arnhem Land. In M. Clark and S.K. May (eds), Macassan History and Heritage: Journeys, Encounters and Influences, pp. 127-139. Canberra: ANU E Press. doi.org/10.22459/MHH.06.2013.08 (accessed 5 June 2018).

Taçon, P.S.C., M. Langley, S.K., May, R. Lamilami, W. Brennan and D. Guse. 2010. Ancient bird stencils in Arnhem Land, Northern Territory, Australia. Antiquity 84(324):416-27. doi.org/10.1017/ S0003598X00066679 (accessed 5 June 2018).

Taçon, P.S.C., N.H. Tan, S. O’Connor, J. Xueping, L. Gang, D. Curnoe, D. Bulbeck, B. Hakim, I. Sumantri, H. Than, I. Sokrithy, S. Chia, K. Khun-Neay and S. Kong. 2014. The global implications of the early surviving rock art of greater Southeast Asia. Antiquity 88(342):1050-1064. doi.org/10.1017/ S0003598X00115315 (accessed 5 June 2018).

Tim Penelitian. 2011. Delineasi Kawasan Cagar Budaya Gua Prasejarah Kars Maros Pangkep. Unpublished report. Makassar: Balai Pelestarian Peninggalan Purbakala.

Valladas, H., J. Clottes and J.-M. Geneste. 2004. Chauvet, la grotte ornée la mieux datée du monde. Pour La Science 42(Temps et Datations special issue):82-87.

Valladas, H., N. Tisnerat, M. Arnold, J. Évin and C. Oberlin. 2001. Les dates des fréquentations. In J. Clottes (ed.), La Grotte Chauvet, les origines del'art, pp. 32-34. Paris: Le Seuil.

van den Bergh, G.D., B. Li, A. Brumm, R. Grün, D. Yurnaldi, M.W. Moore, I. Kurniawan, R. Setiawan, F. Aziz, R.G. Roberts, Suyono, M. Storey, E. Setiabudi and M.J. Morwood. 2016. Earliest hominin occupation of Sulawesi, Indonesia. Nature 529(7585):208-211, doi.org/10.1038/nature16448 (accessed 5 June 2018).

van Heekeren, H.R. 1952. Rock-paintings and other prehistoric discoveries near Maros (South West Celebes). Laporan Tahunan Dinas Purbakala 1950:22-35.

van Heekeren, H.R. 1957. The Stone Age of Indonesia. Verhandelingen van het Koninklijk Instituut voor Taal-, Land- en Volkenkunde 21. The Hague: Martinus Nijhoff.

Walsh, G.L. 2000. Bradshaw Art of the Kimberley. Toowong, Qld.: Takarakka Nowan Kas Publications.

Wesley, D., S. O'Connor and J.N. Fenner. 2016. Re-evaluating the timing of the Indonesian trepang industry in north-west Arnhem Land: Chronological investigations at Malara (Anuru Bay A). Archaeology in Oceania 51(3):169-195. doi.org/10.1002/arco.5091 (accessed 5 June 2018). 
This text is taken from The Archaeology of Sulawesi: Current Research on the Pleistocene to the Historic Period, edited by Sue O'Connor, David Bulbeck and Juliet Meyer, published 2018 by ANU Press, The Australian National University, Canberra, Australia.

doi.org/10.22459/TA48.11.2018.04 